\title{
IMMERSIVE LEARNING OF REAL-WORLD PROBLEMS AND SOLUTIONS: AN INNOVATIVE APPROACH TO ATTRACTING STUDENTS TO COMPUTER INFORMATION SYSTEMS PROGRAMS
}

\author{
Dr. Jensen J. Zhao, Ball State University,jzhao@bsu.edu \\ Dr. MelodyW. Alexander, Ball State University, malexand@bsu.edu \\ Dr. Allen D. Truell, Ball State University, atruell@bsu.edu
}

\begin{abstract}
While the number of college degrees conferred in the U.S. has increased for years, the number of college degrees conferred in computer and information systems in the U.S. decreased by 27\% between 2005 and 2010. Research indicated that the decline was caused by student fear of computer and information technology jobs being outsourced overseas, the dot.com failure, the slow-down economy, and student weak knowledge of computer and information technology. This paper provides a hands-on immersive learning project of real-world problems and solutions and discusses how the project can engage students in immersing into the society, identifying the real-world problems, and generating solutions with computer information technology. Learning through the real-world hands-on activities, students would realize that computer information technology is the foundation for solving business problems in the Internet Age. More students would be excited about the computer information systems programs and be interested in majoring or minoring in computer information systems.
\end{abstract}

Keywords: Computer information systems, critical thinking, creative thinking, real-world problem, immersive learning.

\section{INTRODUCTION}

The college enrollment in the U.S. increased by $11 \%$ between 1990 and 2000. Moreover, between 2000 and 2010 , it increased by $37 \%$, from 15.3 million to 21 million college students. Much of the growth between 2000 and 2010 was in full-time enrollment; the number of full-time students rose $45 \%$, while the number of part-time students rose $26 \%$. As a result, the number of college degrees conferred in the U.S. increased by $33 \%$ between 2000 and 2010 [9].

However, while the number of college degrees conferred in the U.S. increased, a substantial variation existed among different fields of study during this time. For instance, after an increase of $43 \%$ during the dot.com boom between 2000 and 2005, the number of college degrees conferred in computer and information systems in the U.S. decreased by $27 \%$ between 2005 and 2010 , whereas other fields of study were on the rising trends [9].

The enrollment of some undergraduate programs of computer and information systems declined even lower than national average. For example, the Louisiana state universities indicated a decline of $43 \%$ in the number of students seeking the bachelor degrees in computer and information systems at the statewide level since 2000 [8]. To find out the causes to the decline, surveys conducted among students showed that $67 \%$ of the responding students blamed the outsourcing of computer and information technology jobs overseas, $60 \%$ cited the dot.com failure, $40 \%$ indicated that the slow-down economy was cyclical in nature, and $27 \%$ stated the decline in students' analytical abilities [6].

Another survey of college freshmen reported that business students in an introductory business course were knowledgeable about careers in management, marketing, accounting, and finance; but were least knowledgeable about information systems. This suggests that while the students are of the Internet generation, they have little knowledge of, or interest in, computer-related careers [1].

Poliacia's [8] survey of college freshmen identified several reasons for the decline, which involved (a) a lack of accurate career information, (b) the perception of a weak job market, (c) personal likes and dislikes, and (d) a key fact of choosing their major only using self-developed information by $68 \%$ of responding students. Obviously, students were not well informed when choosing majors. 


\section{Issues in Information Systems \\ Volume 15, Issue I, pp. 98-105, 2014}

To reinvigorate the discipline and attract a new generation of students to the undergraduate programs of computer information systems, faculty and professionals are making great efforts, such as bringing in business speakers, hosting job fairs, and forming professional-student mentorships, to assist students for accurate career information of the computer and information systems professions [e.g., 5].

Research indicated that traditional approaches to learning have often focused upon knowledge transfer strategies that have centered on textually-based engagements with students and dialogic methods of interaction with instructors. Rather than the knowledge transfer from instructors and texts to students, hands-on immersive learning allows students to engage in more complex social interactions and to identify real-world problems [3]. However, integrating hands-on immersive learning projects of real-world problems into curriculum is often an overlooked element of designing curriculum and courses [7]. Hands-on immersive learning of real-world problems enables students to identify specific areas where changes can be implemented in the workplace or real-world situation [2].

This paper provides a hands-on immersive learning project of real-world problems and solutions and discusses how the project can engage students in immersing into the society, identifying the real-world problems, and generating solutions with computer information technology. The discussion starts with (a) the problem statement and hypotheses, (b) the immersive learning project design and procedure, (c) immersive learning outcome; concludes with (d) pedagogical and practical implications; and finishes with (e) limitation and recommendation for further research.

The purpose of the project is to help students realize that computer information systems programs would enable students to use information technology for developing innovative solutions to many real-world problems that disturb people of varied age groups and occupations.

\section{PROBLEM STATEMENT AND HYPOTHESES}

The problem addressed in this study was to determine whether the immersive learning project would foster students to identify real-world problems and to develop solutions with computer information technology. In order to investigate the problem, we tested the following three hypotheses:

Hypothesis 1: The immersive learning project would enable students to immerse into the society, communicate with people of varied age groups and occupations, and identify chaos and problems that disturb people at work, at school, at store, or on the road.

Hypothesis 2: The real-world chaos and problems that disturb people at work, at school, at store, or on the road would spark students' interest in brainstorming innovative ideas and developing creative solutions to such problems.

Hypothesis 3: The majority of the student-developed creative solutions to the disturbing chaos and problems would be based on computer information technology.

\section{DESIGN AND PROCEDURE OF IMMERSIVE LEARNING PROJECT}

The immersive learning project was designed as a form of learning in which learners are physically placed themselves in the society to accomplish the following three tasks: (a) to learn from people of varied age groups and occupations about the real-world chaos and problems that people like to have solutions, (b) to work in team, apply their intelligences, brainstorm innovative ideas, and develop solutions to the problems, and (c) to write an innovation proposal for solving a real-world problem that has a great market demand. Specifically, the immersive learning project consists of the following seven stages, which were developed by Isaksen and Trefeinger [4] and enriched by Zhao and Zhao [10].

First, at the Chaos-Finding stage, students immersed themselves into the society and interviewed a sample of people from varied age groups and occupations for collecting the chaos or problems that people encountered in their daily life at home, at work, at school, on the road, at shopping mall, or at airport. When conducting the interview, each student had a list of pre-developed, open-ended interview questions for collecting data (see Appendix A). In addition, 


\section{Issues in Information Systems \\ Volume 15, Issue I, pp. 98-105, 2014}

students were trained on how to foster a customer-centered divergent thinking when finding chaos and how to work in team to prioritize and select one chaos to investigate from a large number of alternatives they got from the interviews.

Second, once the chaos is defined, students moved to the next stage, Data-Finding, by conducting related literature review and analyzing the interview data. Based on the related literature review and interview data analysis, students gathered available information, knowledge, facts, feelings, thoughts, opinions, and questions about the chaos in order to sort out and clarify the chaos more specifically.

Third, after data analysis, students moved to the Problem-Finding stage by considering many possible questions or problem statements based on customer-centered divergent thinking. Students were advised to put aside the common assumption that they "already know what the problem is" and to try to state the problem in such a manner as to invite novel perspectives on it. Then, in a convergent way of thinking, they wrote down statements of the problem and the market need for solution that they believed would do the best job of expressing the "heart" of the situation of the problem.

Fourth, when the problem was clearly defined, students moved to the Idea-Finding stage. At this stage, the instructor taught students how to brainstorm innovative ideas by applying various creative thinking approaches such as customer-centered thinking, imaginative thinking, associative thinking, combinational thinking, transplantable thinking, interdisciplinary thinking, and convergence thinking. Students brainstormed as many ideas or alternatives as possible for responding to the problem statement. The more ideas they could produce, the greater the likelihood that some would represent promising solutions to the problem.

Fifth, in the Solution Finding stage students worked together to identify the promising solutions from students' ideas. Students first considered many possible criteria for evaluating their ideas and then selected the criteria that they decide were the most important or necessary to evaluate the ideas' strengths, weaknesses, opportunities, and threats. The result of this stage is to identify which idea or ideas offer the greatest potential for solving the problem and bringing a greatest return on the investment.

Sixth, having decided on a solution, students moved to the Acceptance-Finding stage. At this stage, students first considered the specific elements that would promote successful implementation of their solution, such as what kind of help they would need, what obstacles or difficulties might get in the way. Second, in convergence, students decided what implementation steps would be most important. And then they developed a specific, step-by-step action plan that they would take to get rid of that original chaos.

Finally, students would write a team proposal for solving a real-world chaos or problem. The proposal would consist of the following six major sections: (a) introduction, (b) problem statement, (c) market needs, (d) innovative idea with a SWOT analysis, (e) action plan, and (f) request for accepting the proposal. After finishing their team proposals, student teams would present their proposals to company managers or potential investors who might be interested in their innovative solutions to those real-world problems.

\section{IMMERSIVE LEARNING OUTCOME}

Hypothesis 1 stated: "The immersive learning project would enable students to immerse into the society, communicate with people of varied age groups and occupations, and identify chaos and problems that disturb people at work, at school, at store, or on the road."

We assigned this immersive learning project to students in a sophomore business communication course in a Midwest state university because the university strategic plan of 2012-2017 requires to place immersive learning at the center of the university education. A total of 231 students were trained to work on the project and formed 77 project teams, with each having three members. Students learned that one of the best ways to identify chaos and problems that disturb people is to conduct an interview survey for collecting data. Therefore, after the team formation, each member was required to interview three people in varied age groups and occupations by following 
the interview questionnaire, which could collect approximately 12 chaos or problems from each interviewee (see Appendix A).

As Table 1 illustrate, each team of three members collected 108 chaos and problems from nine people of varied age groups and occupations, whom they had interviewed. Seventy-seven teams in this study collected 8,316 chaos and problems that were disturbing people in their daily life at the time of interviews. Therefore, Hypothesis 1 was supported.

\begin{tabular}{|c|c|c|}
\hline \multicolumn{3}{|l|}{$\begin{array}{c}\text { Table } 1 \\
\text { Total Number of Problems that Interviewees Reported as Disturbing their Life }\end{array}$} \\
\hline Number of chaos and problems per each questionnaire to collect & & 12 \\
\hline Number of people per member to interview & $\mathrm{x}$ & 3 \\
\hline Number of members per team & $\mathrm{x}$ & 3 \\
\hline Number of chaos and problems each team collected & & 108 \\
\hline \# of total teams & $\mathrm{x}$ & 77 \\
\hline Total number of chaos and problems disturbing people in their daily life & $=$ & 8,316 \\
\hline
\end{tabular}

Among the 8,316 chaos and problems disturbing people, the most frequently identified ones were (a) difficulty of remembering assignment due dates; (b) difficulty of being organized with homework and daily life; (c) difficulty of finding the right item while shopping; (d) difficulty of finding one's way at airports, shopping malls, and amusement parks; (e) drivers texting messages while driving; (f) drunk drivers driving on the road; (g) long waiting time at restaurants; (h) lots of time wasted when shopping at stores and malls; (i) restricted school meal plans; (j) communication barrier in foreign countries; (k) credit card fraud on the rise; (l) students waiting for school buses by standing in freezing weather; $(\mathrm{m})$ difficulty of remembering personal IDs and passwords of multiple accounts; and (n) too much paperwork to fill out when visiting medical emergency center.

Hypothesis 2 stated: "The real-world chaos and problems that disturb people at work, at school, at store, or on the road would spark students' interest in brainstorming innovative ideas and developing creative solutions to such chaos and problems."

After analyzing the interview data and reviewing the related literature, each of the 77 teams narrowed down from around 108 chaos to one well-defined problem that has a great market demand to resolve it. Working through the process of defining problems and exploring market demand, students were inspired to brainstorm innovative ideas and creative solutions to the problems. During the brainstorm session at Idea-Finding stage, students in each team applied various creative thinking skills and generated multiple innovative ideas for solving the problems. Then, students conducted the SWOT analysis of each idea to select the most innovative and feasible solution, which has the great market potential. Table 2 presents a sample of problems and their respective solutions proposed by student teams. Some solutions, such as the real-time bus schedule application and the flexible school meal plan card, were developed and now are used on some university campuses. Therefore, Hypothesis 2 was supported.

Hypothesis 3 stated: "The majority of the student-developed creative solutions to the disturbing chaos and problems would be based on computer information technology."

As Table 3 presents, among the 77 immersive learning project proposals, 64 (83\%) proposed solutions were ITbased solutions to the problems and only $13(17 \%)$ proposed solutions were non-IT related. Therefore, Hypothesis 3 was supported. 


\begin{tabular}{|c|c|c|}
\hline \multicolumn{3}{|c|}{$\begin{array}{c}\text { Table } 2 \\
\text { Sample of Problems and Solutions Proposed by Student Teams }\end{array}$} \\
\hline Problem & Solution & $\begin{array}{c}\text { IT } \\
\text { based? } \\
\text { yes/no }\end{array}$ \\
\hline $\begin{array}{l}\text { - Communication barrier in } \\
\text { foreign countries }\end{array}$ & $\begin{array}{l}\text { A mobile application of Google translator for cell-phones and } \\
\text { other mobile devices so that travelers can use it for language } \\
\text { translation when going to foreign countries. }\end{array}$ & Yes \\
\hline - Credit card fraud on the rise & $\begin{array}{l}\text { A "Speedy-Swipe Handheld Mobile" device for restaurants, so } \\
\text { that a waiter or waitress will simply swipe a debit or credit card } \\
\text { right in front of a customer and print the receipt on spot. }\end{array}$ & Yes \\
\hline $\begin{array}{l}\text { Difficulty of being organized } \\
\text { with homework and daily life }\end{array}$ & $\begin{array}{l}\text { A "Life Planner," an Internet application that can help people be } \\
\text { organized in different aspects of their life. }\end{array}$ & Yes \\
\hline $\begin{array}{l}\text { Difficulty of finding one's way } \\
\text { at airports, shopping malls, and } \\
\text { amusement parks; }\end{array}$ & $\begin{array}{l}\text { A mobile application that lets different clients upload dynamic } \\
\text { maps and layouts with GPS to their smart phones and other } \\
\text { mobile devises for navigation. }\end{array}$ & Yes \\
\hline $\begin{array}{l}\text { Difficulty of finding the right } \\
\text { item while shopping }\end{array}$ & $\begin{array}{l}\text { Stores could set the Internet screen panels in store allowing } \\
\text { shoppers to search for items and their prices and locations. }\end{array}$ & Yes \\
\hline $\begin{array}{l}\text { - Difficulty of remembering the } \\
\text { assignment due dates }\end{array}$ & $\begin{array}{l}\text { An Internet application that updates students' cell phones with } \\
\text { assignments, tests, and other upcoming due dates from a course } \\
\text { management solution such as Blackboard and then creates a text } \\
\text { reminder on students' cell phones. }\end{array}$ & Yes \\
\hline $\begin{array}{l}\text { Difficulty of remembering } \\
\text { personal IDs and passwords of } \\
\text { multiple bank and financial } \\
\text { accounts }\end{array}$ & $\begin{array}{l}\text { A biometric banking system with finger print scanner into all } \\
\text { bank and financial websites and ATMs. Thus, customers can } \\
\text { just use their fingers to access their accounts without passwords. }\end{array}$ & Yes \\
\hline $\begin{array}{l}\text { Drivers text messages while } \\
\text { driving }\end{array}$ & $\begin{array}{l}\text { A sensor on vehicles that does not allow phone calls and text } \\
\text { messages while car is in motion. }\end{array}$ & Yes \\
\hline $\begin{array}{l}\text { Drunk drivers driving on the } \\
\text { road }\end{array}$ & $\begin{array}{l}\text { A sensor installed on vehicles, which would lock the ignition } \\
\text { when sensing alcohol from the driver. }\end{array}$ & Yes \\
\hline - $\quad$ Long waiting time at restaurants & $\begin{array}{l}\text { A dinning website where customers can see real-time } \\
\text { information of local restaurants: where they are located, how } \\
\text { busy they are, if or not they take reservations, and if or not they } \\
\text { take orders while waiting for seats. }\end{array}$ & Yes \\
\hline - $\quad$ Restricted school meal plans & $\begin{array}{l}\text { Making students' meal cards as a debit card usable at local } \\
\text { restaurants around the schools, so that students can have more } \\
\text { variety of meals each day. }\end{array}$ & Yes \\
\hline $\begin{array}{l}\text { Student fear of taking classes } \\
\text { from professors who would not } \\
\text { help students meet their } \\
\text { learning needs }\end{array}$ & $\begin{array}{l}\text { A website allowing students to view potential professors } \\
\text { teaching classes so that they can make an informed decision } \\
\text { about which professors they wish to sign up for. }\end{array}$ & Yes \\
\hline $\begin{array}{l}\text { Students waiting for bus in } \\
\text { freezing weather }\end{array}$ & $\begin{array}{l}\text { An Internet-based real-time bus schedule application for } \\
\text { students to download to their cell phones and other mobile } \\
\text { devices so that they can get to a bus stop just-in-time when a bus } \\
\text { arrives. }\end{array}$ & Yes \\
\hline
\end{tabular}




\begin{tabular}{|l|c|c|}
\hline \multicolumn{3}{|c|}{ Table 3 } \\
Types of Student-Proposed Solutions \\
\hline Type of Solution & Frequency & Percentage \\
\hline IT-based solutions & 64 & $83 \%$ \\
\hline Non-IT-based solutions & 13 & $17 \%$ \\
\hline Total & 77 & $100 \%$ \\
\hline
\end{tabular}

Furthermore, Table 4 illustrates the business areas where chaos and problems were identified and to which the solutions were proposed. Of the 64 IT-based solutions, the solutions for improving restaurant service were the most frequently proposed $(n=13,20 \%)$, followed by the daily planner/planning schedule solutions $(n=7,11 \%)$, solutions to texting while driving/drunk driving $(n=6,9 \%)$, solutions for improving the shopping mall service $(n=$ $5,8 \%) \ldots$ and $27 \%$ were in other areas such as solutions to the poor public transportation between an airport and small cities and towns, to the traffic congestion during rush hours, and to defrosting car windows in freezing winter.

\begin{tabular}{|c|c|c|}
\hline \multicolumn{3}{|c|}{$\begin{array}{c}\text { Table } 4 \\
\text { Problem Areas Needing Solutions for Improvement }\end{array}$} \\
\hline Problem Area & Frequency & Percentage \\
\hline - Restaurant service & 13 & $20 \%$ \\
\hline - Daily planner/planning schedule & 7 & $11 \%$ \\
\hline - Texting while driving/drunk driving & 6 & $9 \%$ \\
\hline - Shopping mall service & 5 & $8 \%$ \\
\hline - Airport/museum/amusement park & 4 & $6 \%$ \\
\hline - Household chores & 4 & $6 \%$ \\
\hline - Language translation & 3 & $5 \%$ \\
\hline - Dining on campus & 3 & $5 \%$ \\
\hline - School bus service & 2 & $3 \%$ \\
\hline - Others & 17 & $27 \%$ \\
\hline Total & 64 & $100 \%$ \\
\hline
\end{tabular}

\section{PEDAGOGICAL AND PRACTICAL IMPLICATIONS}

Incorporating immersive learning project into the design and delivery of real-world hands-on assignments has the following pedagogical and practical implications.

First, the immersive learning project would enable instructors to direct students to immerse into the society, communicate with people of varied age groups and occupations, and identify real-world problems that disturb people in their life and need solutions. Such problems may draw some companies' and venture capitalists' attention as opportunities for developing new business solutions.

Second, learning through the immersive project, students would be able to apply critical and creative thinking and problem-solving skills along the seven-stage procedure of chaos-finding, data-finding, problem-finding, ideafinding, solution-finding, acceptance-finding, and proposal writing and presentation. Thinking critically and creatively of the disturbing problems and the market demand for solving the problems would inspire students to generate innovative solutions. Such innovative solutions will attract potential investment from some companies and venture capitalists. 


\section{Issues in Information Systems \\ Volume 15, Issue I, pp. 98-105, 2014}

Moreover, knowing that the majority of their solutions to the real-world disturbing problems are based on computer information technology, students would realize that computer information technology is the foundation for solving business problems in the Internet Age. Therefore, more students would be excited to take the computer information systems programs or courses.

Finally, computer information systems instructors could consider working with instructors teaching 100- and 200level business courses and incorporating this type of immersive learning project into their courses to make the courses real-world and hands-on related. Furthermore, the project would enable students to learn that many realworld chaos and problems can be resolved with computer information technology; therefore, more students would be attracted to the computer information systems programs.

\section{LIMINATION AND RECOMMENDATION FOR FURTHER RESEARCH}

The generalizability of the findings in this pedagogical study is limited to the undergraduate business students holding characteristics similar to this Midwestern state university. Therefore, replications of this study should be undertaken in universities on the east or west coast where student body has a more diversified ethnic composition. In addition, follow-up studies should be conducted to investigate the impact of such immersive learning projects on students' selection of majors, minors, elective courses, and careers.

\section{REFERENCES}

1. Crampton, William J., Walstrom, Kent A., \& Schambach, Thomas P. (2006, October) "Factors influencing major selection by college of business students", Issues in Information Systems, October 2006, International Association for Compute Information Systems, 7(1), 226-230.

2. Foxon, M. (1987). Transfer of training: A practical application. Journal of European Industrial Training, 11(3), 17-20.

3. Freitas, S. D., Rebolledo-mendez, G., Liarokapis, F., Magoulas, G., \& Poulovassilis, A. (2010). Learning as immersive experiences: Using the four-dimensional framweork for designing and evaluating immersive learning experiences in a virtual world. British Journal of Educational Technology, 41(1), 69-85.

4. Isaksen, S. \& Treffinger, D. (1985). Creative Problem Solving: The Basic Course. Buffalo, NY: Bearly Limited.

5. Kohun, F. G., Luce, T., Ross, S.C., \& Saulnier, B. M. (2012). The future of information systems education: What have we done to grow enrollment? Keynote Panel Presentation at the 2012 Annual Conference of the International Association for Computer Information Systems, Myrtle Beach, SC.

6. Lenox, Terri L., Charles R. Woratschek, \& Gary A. Davis (2005, October) "Exploring Declining CS/IS/IT Enrollments", Proceedings of ISECON 2005, v22, Columbus, OH, Oct. 2005.

7. Mills, R. J., Hauser, K., \& Pratt, J. A. (2008). A comprehensive two-level framework for information systems curriculum design, assessment and improvement. Journal of Computer Information Systems, 48(4), 1-14.

8. Pollacia, L. (2007). Declining CIS majors and students' perceptions of the IT profession. Proceedings of the 2007 Southern Association for Information Systems Conference. Retrieved from http://sais.aisnet.org/2007/SAIS07-13\%20Pollacia.pdf

9. U.S. Department of Education, National Center for Education Statistics. (2012). Digest of Education Statistics, 2011 (NCES 2012-001), Chapter 3. Retrieved from http://nces.ed.gov/fastfacts/display.asp?id=98

10. Zhao, J. J. \& Zhao, S. Y. (2010). The impact of IQ+EQ+CQ integration on student productivity in Web design and development. Journal of Information Systems Education, 21(1), 43-53. 


\section{APPENDIX A \\ INTERVIW QUESTIONNAIRE FOR FINDING REAL-WORD CHAOS AND PROBLEMS}

Instruction: One of the best ways to identify chaos and problems that disturb people in their daily life is to conduct a survey. The survey findings will help you generate ideas for developing innovative solutions to the chaos and problems. Make sure to interview a variety of people of different ages and occupations (e.g., your parents, grandparents, friends, colleagues at work, or roommates at school). The more people you talk to, the more chaos you will find and the more ideas you will get.

You are required to interview three people in varied age groups and occupations. Use the following questionnaire as your interview instrument.

Date:

1

_Female/_Male

Age Groups: _ 15-25, _ 26-35,_36-45,_46-55,_56-65,_66+

Occupation: _ _ Student _ _ Business Owner $\quad$ Retiree Employee _Please specify: _ _ Home Executive

Questions:

1. What does not work _ in your life or _ on your job, but you would like it to work?

2. What problem _ _ in your life or _ on your job would you like to see solved?

3. What product or service would you like to have but not available to you now?

4. If you could invent something to make your life easier, what would you invent?

5. What is the most disturbing problem to you in each following environment and how would you like to solve it?
a) at home:
b) at school:
c) at work:
d) at the airport:
e) on the road:
f) at the shopping center:
g) at the bank:
h) at the restaurant:

-Thank You - 